\title{
Exploring pop-up cinema and the city: Deleuzian encounters with secret cinema's pop- up screening of The Third Man
}

Ella Harris, University of London

\begin{abstract}
In this article I mobilize Deleuze to explore transformative relationships between filmic and urban space in Secret Cinema’s pop-up screening of Carol Reed's The Third Man (1949). Secret Cinema is a company that turns urban sites into dramatized versions of the films they screen, and this unusual practice of exhibition raises fascinating questions about how film texts and urban sites come into contact. In particular, I respond to two crucial questions that are provoked by Secret Cinema’s ‘immersive’ screening of The Third Man. First, I consider the impact this kind of filmic experience has on ways of seeing the urban, drawing on the Deleuzian concept of the any-space-whatever. Second, I take up Deleuze’s ideas about the out-of-field and its differing functions within the movement-image and the time-image to address how Secret Cinema’s dramatized site of spectatorship reciprocally transforms the meaning of film text and urban space. By addressing these two questions, and with comparative reference to early cinema's practices of exhibition, I develop a nuanced reading of Secret Cinema’s screening as a co-production of filmic and urban space.
\end{abstract}

\section{Keywords}

Deleuze

pop-up cinema

The Third Man

any-space-whatever 
out-of-field

film spectatorship

On 22 December 2011, I open my e-mails to find the last of three cryptic correspondences from Secret Cinema, which I have booked tickets to attend the following month. The e-mail contains an image of a 'wireless communication' that looks like it dates from the 1920s. Embedded within the typewriter-style font are hyperlinks leading to instructions on where to go on the day of the screening and pictures showing what to wear. I have been assigned the category of 'Rogue' but from the multiple dress codes can see that others have been designated 'Guardians' from the 'International Police Headquarters' and 'Esteemed Visitors' from the 'British Cultural Office'.

\section{$<<$ insert Fig.1 here $>>$}

$<<$ insert Fig. 2, Fig. 3, Fig. 4 here $>>$

Following one hyperlink takes me to a map on which the 'international zone' has been located to the north of Barbican tube station. Some roads have been given German names, and others French, but the map is recognizable as central east London.

$<<$ insert Fig. 5 here $>>$

1 
A month later, in January 2012, I arrive at Barbican station with two friends, feeling selfconscious in my slightly half-hearted costume. As we approach the meeting-point we start to see other people dressed up and notice a woman holding balloons, who we were told to look out for. Everyone begins to funnel down the same alleyway, and I feel a surge of excitement. Lots of people have gone to town with their costumes and I can't tell the difference between the audience and the actors. Policemen scream at us in German to line up against the wall, and then march us through the streets. We pass some trade vans unloading meat carcasses, which it takes me a while to realize aren't part of the set; they seem subsumed within the fictional world we're being led into. In fact everything incongruent seems to go out of focus as more characters emerge from behind each corner. An old man who looks Russian glares at us from one of the dimly lit back streets, a woman with a briefcase hurries away, appearing terrified, and some of the officers leading us splinter off to chase a young man who has bolted through the crowd. Eventually we arrive at a grand building and are asked to change our money into the 'currency' of the site. The entranceway is decorated like a 1920s bar or hotel, and up the wide stairs we can hear a band playing. There are sweet stalls, cafes, a cart selling candy floss and for some reason piles of rubble on the floor and in the corners. There are seemingly infinite doors, staircases and corridors. We don't know where to start. It feels like something, although I don't know what, is about to happen.

\section{Introduction}

These ethnographic notes describe my attendance of Secret Cinema’s screening of Carol Reed's The Third Man (1949), which took place in the Farmiloe building in Barbican, London, in January 2012. Secret Cinema is a London-based film-screening company that, since their launch in 2007, have been the forerunners in the city’s trend for 'pop-up' cinema. 
Pop-up cinema, a growing phenomenon across the global north (Pratt and San Juan 2014), is defined by its spatio-temporality and incorporates a spectrum of temporary and site-specific film-screening practices. Secret Cinema is notable for putting on 'immersive' events in vacant spaces, temporarily transforming them into theatrical versions of the films they show. Visitors explore these sites before the screening and can buy food and drink, enjoy entertainment and interact with props and characters. What the film will be remains undisclosed until, at the end of the night, the spectators are ushered into a room and the movie begins.

If uncanny experiences of the cinematic have long been felt in the city, then Secret Cinema plays on the porous boundary between the cinematic and the urban. It has been argued that cinema always has the potential to leak out into the city and vice versa (Clarke 1997: 3), and Secret Cinema stages that leakage performatively, deliberately bringing films into imaginative relation with London's urban environments. The significance placed on site calls for attention to the interplay of urban and filmic space in pop-up film screenings. However, to date there is little sustained analysis of these interactions. Geraldine Pratt and Rose Marie San Juan (2014) have advanced particular dimensions of pop-up cinema's urban engagements through their exploration of its critical potential in public space, but further attention is needed on how particular films are mediated through and transformative of popup sites of spectatorship. This article speaks to that gap, conducting an in-depth exploration of Secret Cinema's screening of The Third Man. Specifically, the theatrical way in which Secret Cinema's screening of that film employs the city provokes two critical questions pertaining to the relationship between filmic and urban space. First, what impact does this kind of filmic experience have on ways of encountering the urban? If cinematicity can be understood as a way of seeing, generated by the language of film and its technologies of exhibition (Crary 2002, 1990; Clarke and Doel 2005), then what ways of seeing does the 
spatiotemporal language of Secret Cinema generate? And second, given longstanding calls to read films through the geographies of their production and exhibition (Zonn 2007; Roberts 2012; Aitken and Dixon 2006; Cresswell and Dixon 2002; Shiel and Fitzmaurice 2001), how does Secret Cinema's dramatized site of spectatorship transform the meaning of the film text, and vice versa?

The article is split into two main sections that address, in turn, the questions raised above. In approaching these questions, I mobilize Gilles Deleuze’s ideas in Cinema 1 and Cinema 2 where he interrogates how film expresses and produces movement and time (Deleuze 2005, 2013). Influenced by the philosophy of Henri Bergson, time, for Deleuze, must entail the production of the qualitatively new, rather than merely the unfolding of the pre-given, meaning it is always generative and transformative. In the emerging scholarship on pop-up cinemas it has been argued that their temporary and site-specific nature makes them spaces where new trajectories for action are produced, as urban sites are enveloped in and altered through the ludic and critical capacities of pop-up film (Pratt and San Juan 2014; Lashua 2013). Deleuze’s Bergsonian-inspired philosophy is therefore a fitting means with which to approach pop-up cinema, enabling attentiveness to temporality and transformation. My use of Deleuze takes up concepts he developed to address filmic images and uses them to explore assemblages of the filmic and the urban. This mobilization of Deleuze responds to Secret Cinema's own performative leakage of cinema into the city, bringing concepts built for the screen to bear on the intersection of filmic and 'real' space. As others have noted, the dynamism of Deleuzian thought allows his concepts to be translated into new contexts while retaining their force and focus (O'Sullivan 2006). Moreover, using Deleuze’s work on cinema to approach film's intersections with the urban speaks to Deleuze's wider ontology, which is premised on the importance of interactions between heterogeneous parts and interested in how those interactions produce change and movement. In taking up Deleuzian concepts to 
approach Secret Cinema I am therefore not only illuminating the interplay of film images and urban space in pop-up exhibition but demonstrating and advancing the exciting potentials of Cinema 1 and Cinema 2 for exploring the meeting of real and 'reel' space.

In particular, I take up two Deleuzian concepts to understand the relationships between urban and filmic space elicited by Secret Cinema: that of the any-space-whatever and that of the out-of-field and its differing workings in the movement-image and in the timeimage. In the first section of this article, I explore how Secret Cinema sees urban space, characterizing this way of seeing against Deleuze's notion of the any-space-whatever. Deleuze's 'any-space-whatever' is an indeterminate or empty filmic space 'whose parts are not yet linked in a given trajectory of movement' (Rodowick 1997: 64). I mobilize this concept to approach Secret Cinema as both an event that takes over empty city spaces and a practice that deterritorializes and reterritorializes both films and urban sites by engaging them in new relations to one another. In the second section, I employ the idea of the out-of-field to consider how the 'meaning' of the immersive film event is generated when filmic and urban space enters into such relations. The out-of-field is an idea that Deleuze develops to explain how the movement-image works, and refers to the process through which filmic images gesture towards something off-screen, although in the time-image (as we will see) it takes a different form. Using this theory of how film images relate to what is beyond them, I explore how, in Secret Cinema, film images relate beyond themselves to the site of exhibition. In adapting these Deleuzian concepts to address the interplay of filmic and urban space in immersive screenings I take inspiration from accounts of early film spectatorship, many of which consider how 'live' elements of screenings alter the functions of a film text. Secret Cinema has interesting parallels with early cinema screenings and exploring these can illuminate the effects of its immersive spectatorship. Before embarking on the article's main two sections, I first introduce the relevance of certain ideas about early film exhibition for 
studying pop-up cinema and, in bringing these ideas into contact with Deleuze, show how they help to approach Secret Cinema’s site-specific event.

Pop-up culture, as many have commented, responds to the prevalence of vacant sites and buildings in post-recession cities (Colomb 2012; Tonkiss 2013; Graziano and Ferreri 2014; Deslandes 2013). Pop-up cinemas, in particular, are notable for imaginative approaches to those sites. Although pop-up screenings are varied, Secret Cinema, which is the preeminent pop-up cinema in London, is paradigmatic of key ways that pop-up cinemas engage with urban space. Secret Cinema develops elements of what Pratt and San Juan term 'serious play’ (Pratt and San Juan 2014), where pop-up cinemas occupy disused sites to foster engagement with urban issues. Fabien Riggall, Secret Cinema’s founder, has argued that Secret Cinema allows spectators to relate films to real life (see Rosser 2014); examples of this include a screening - in Tottenham, where the London riots of 2011 began - of La Haine (Kassovitz, 1995), a film centred on riots in the Parisian banlieues. Secret Cinema is also the most extravagant enactment of the tendency for 'immersive' experiences within pop-up cinema, where, as described in the opening ethnographic account, film worlds are expanded into 'real' space, offering haptic encounters with dramatized urban settings.

The importance of site in Secret Cinema's screenings resonates with certain aspects of early and pre-cinematic spectatorship. Like Secret Cinema’s immersive screenings, many early sites of spectatorship were decorated to mimic the internal geographies of the films shown. For example, Tom Gunning has described how Hale’s Tours, which featured shots taken from moving trains, were staged in an imitation train-carriage with conductors taking tickets (Gunning 1986). David Clarke and Marcus Doel similarly describe how, at the TransSiberian railway Panorama, spectators 'sat on the deck of a ship, which was made to pitch and roll' (Clarke and Doel 2005: 48). Additionally, the way Secret Cinema couples film exhibition with other forms of consumption and entertainment is reminiscent of Vaudeville 
shows. As Miriam Hansen has described, Vaudeville shows programmed film alongside other entertainment, including live music, sing-alongs, lectures, sound effects and stereopticon shows (1991: 43), these live elements forming a crucial part of the experience of the screening.

If ‘every period constructs its spectator in a new way’ (Gunning 1986: 70), then parallels with pre- and early cinematic spectacles provide a starting point for interrogating Secret Cinema’s construction of film experiences, helping to focus on the physicality and performativity of the exhibition site. Two main ideas from scholarship on early cinema and pre-cinematic technologies, developed through Deleuze, will be employed to assist in approaching the two questions of how Secret Cinema sees the city and how its sites transform the meaning of the film text and vice versa. First, in addressing the ways of seeing that Secret Cinema generates, I have in mind how regimes of vision have evolved historically alongside cinematic technologies. As Clarke and Doel note, Jonathon Crary is influenced by Deleuze when he argues that, in the early nineteenth century, a transition from panoramic to stereoscopic technologies occurred in tandem with shifts in regimes of vision. Such shifts relate to a 'double movement' of deterritorialization and reterritorialization with regard to vision whereby vision was liberated from 'the constraints exemplified by the camera obscura' and recuperated for 'the service of abstraction, circulation and indifferent exchange' (Clarke and Doel 2005: 53). In this vein, I explore how Secret Cinema reterritorializes ways of seeing and, specifically, argue that the way it casts urban sites can be understood against the Deleuzian notion of the 'any-space-whatever'. Here, positioning immersive pop-up cinema in a lineage of cinema's relation to shifting regimes of vision allows me to explore how in Secret Cinema the Deleuzian any-space-whatever becomes, as well as a quality of filmic space, a cinematic way of seeing the city. 
Second, I draw on Miriam Hansen’s argument that, at early screenings, a ‘perceptual continuum' was created between the worlds on and off screen (Hansen 1991: 93), bringing filmic space into 'real' space and vice versa. For Hansen, this happened because early screenings were accompanied by live entertainment, which differed from venue to venue but invariably altered the experience of the films. Hansen argues that the attentions of audiences moved fluidly between the on-screen and off-screen events, which co-produced the experience. These descriptions resonate with the joint roles of on-screen and off-screen entertainment at Secret Cinema. Here I develop Hansen’s arguments through Deleuze in order to consider how a perceptual continuum functions in the particular context of Secret Cinema. I envisage the perceptual continuum Hansen describes as generated through a reciprocal deterritorialization and reterritorialization of filmic and urban space and use Deleuze's idea of the out-of-field to explore in detail how 'meaning' is produced within it. In doing so, I develop a particular, Deleuzian approach to reading film and site as inextricable (Zonn 2007). I move away from accounts of spectatorship in which generic exhibition spaces are 'considered separately from the film on view' (Pratt and San Juan 2014: 143) to address film screenings as specific assemblages of film text and urban site. Most significantly, this approach is alert to how the 'meaning' of a film-screening event is co-produced by the onscreen and off-screen, an attentiveness crucial for studying Secret Cinema, where the film shown is mediated through the site that, reciprocally, has been designed around it.

\section{Secret Cinema as a way of seeing: Any-space-whatever}

Pop-up geographies are commonly regarded as indeterminate spaces. Pop-ups usually occupy gaps left by dereliction in the aftermath of recession and 'interim' sites awaiting or undergoing redevelopment. It is generally argued that they demonstrate the capacity of such 
spaces to be re-imagined and used in alternative ways (Iveson 2013; Nemeth and Langhorst 2014; Tardiveau and Mallo 2014). Pratt and San Juan echo this sentiment with particular reference to pop-up cinema, arguing that pop-up cinemas are 'liminal places' (2014: 171) that 'offer unexpected possibilities for cultural innovation and a range of informal and formal underground and autonomous activities' (2014: 167). Brett Lashua has framed the effects of pop-up cinema in Deleuzian terms. He describes how a pop-up cinema in an old textile Mill in Leeds engaged with the history of 'Great Britain’s textile industries' and 're-territorialized the site, adding contemporary meanings tied to a community's sense of identity and place’ (Lashua 2013: 130). Deleuze’s account of deterritorialization and reterritorialization gains a particular force in the context of pop-up cinema. Lashua emphasizes the capacities of urban sites to be reterritorialized through pop-up film screenings, and Secret Cinema's events, as I will explore, destabilize and remake not just urban sites but filmic space too, meaning that, here, deterritorialization and reterritorialization describe a reciprocal alteration of film and site.

In this section I argue that Secret Cinema’s capacity for a mutual deterritorialization and reterritorialization of both filmic and urban space, as demonstrated in its screening of The Third Man, generates a way of seeing the city that can be characterized against Deleuze's idea of the 'any-space-whatever'. Deleuze's concept of the any-space-whatever refers to filmic spaces such as ‘disused warehouses’ or 'cities in the course of demolition' (Deleuze 2013: x). These are sites that have lost their determination because their usual functions have been disrupted (Deleuze 2005: 113), undoing their established relations with other spaces and their usual trajectories of movement (Deleuze 2013: x). Deleuze argues that, in the absence of a normative function, such spaces are open to potentially infinite new relations, making them at once no space and any space at all. 
As Lashua notes, pop-up cinema is already premised on an understanding of urban space as indeterminate and ripe for reterritorializations. In fact, the urban sites occupied by Secret Cinema and other pop-ups are reminiscent of Deleuze's examples of any-spacewhatevers in film: vacant city spaces awaiting demolition or re-use. Pratt and San Juan have noted that Deleuze's description of any-space-whatevers, although intended to describe filmic spaces, can be applied to cinema spaces themselves (Pratt and San Juan 2014: 161) in as much as they offer unexpected possibilities for thinking about and acting in urban space (2014: 167). I would argue that this is particularly true for pop-up cinema spaces. The very premise of pop-up is that urban space can be used in multiple and ever-changing ways. Popup space-finding companies such as ‘Somewhereto', ‘Appearhere’ or ‘Pop Up Republic’ list numerous urban sites 'ready to be filled with your idea' (Appearhere 2015), asserting the contingency of a site's former determinations and its ability to be reterritorialized by each new user. As a pop-up, Secret Cinema's screening in the vacant Farmiloe building therefore indicates the potential of that site to enter into manifold new relations, enacting just one of these through its particular transformation of the space.

Against this background of pop-up culture's assertion of spatial indeterminacy, the way that Secret Cinema makes site and film refer to each other (as co-productive of an imaginative world) deterritorializes and reterritorializes not just urban space but filmic space too. The mutual reference that film and site are brought into enacts an expansion of the film's territory into urban space and vice versa. Through this reciprocal invasion, the internal relations of both spaces are destabilized as they cease to be circumscribed systems, becoming an assemblage forged through new, extraverted relations. It is in this way that Secret Cinema's screening can be interpreted as constructing a way of seeing urban space as an anyspace-whatever. By repurposing vacant urban sites, it, like other pop-up places, asserts the contingency of current spatiotemporal regimes in cities. Then, building on this first 
indeterminacy of urban space it creates a further indeterminacy by mutually destabilizing the filmic and urban territories it employs as they come into contact and alter one another. This mutual indeterminacy becomes a way of seeing because it is fundamental to Secret Cinema's mode of spectatorship. As in the early cinema screenings Hansen describes, the audience's attention at Secret Cinema events is spread across the deterritorialized assemblage of filmic and urban space, which together make up the event's action. Understanding the event therefore requires a perceptual sensitivity to the way that the site is deterritorialized and reterritorialized through its relation with the film. Thus, Secret Cinema’s mode spectatorship requires and constructs attention to spatial indeterminacy, generating a way of seeing urban space as an any-space-whatever.

The construction of a way of seeing premised on the mutual instability of filmic and urban space in Secret Cinema's screening of The Third Man came into view particularly clearly in a number of instances. This section explores two of those in order to develop my account of how Secret Cinema sees urban sites as an 'any-space-whatever'. Before doing so I give a brief account of the film's plot to aid understanding. The Third Man is a film noir set in occupied, post-war Vienna in which the protagonist, Holly Martins, must uncover what 'really happened' to his friend Harry Lime. Holly had come to Vienna to visit Harry but hears that Harry has been run over and killed. Unsatisfied by the explanations given by others, he takes it upon himself to discover the truth. What he finds is that Harry faked his own death after having been caught selling diluted penicillin for profit, deceiving even his lover, Anna. While Holly is usually a fiction writer, uncovering the construction of a fiction becomes his task as he seeks out clues in an unyielding city, trying to unpick the narrative that, as he comes to realize, Harry has put together.

My first example of Secret Cinema’s mutual destabilization of filmic and urban space relates to its staging of Harry’s death. In the film Holly revisits the site of Harry's supposed 
death several times as he tries to work out what happened. Each time different characters give conflicting statements, pacing the space and mapping their story against its coordinates. In Deleuze's description of the any-space-whatever as a disconnected space, he argues that 'The connection of the parts of space is not given because it can come about only from the subjective point of view of a character who is nevertheless absent, or has even disappeared, not simply out of frame, but passed into the void' (Deleuze 2013: 8). Here, in the absence of Harry (who has indeed disappeared), the space itself yields no evidence capable of determining whose account is true; thus each has equal weighting as a version of 'what really happened' there, illustrating how easily the meaning of a space can be rewritten. The scene of Harry’s death is then, clearly, an any-space-whatever, and in its staging Secret Cinema both enhanced the indeterminacy of this filmic any-space-whatever and used it to assert the plasticity of its own site. By staging their own version of 'what really happened' to Harry, Secret Cinema added yet another layer of interpretation to the mystery, thereby further destabilizing the filmic space by asserting that its potentials to be re-narrated are not limited to those already contained within the film’s drama. Furthermore, by staging Harry's death within the Farmiloe building Secret Cinema asserted the malleability of London's own urbanfabric, which, like the site of Harry's death, can be mobilized towards the telling of multiple stories. This performance then enforced a sense of how easily the urban fabric, both within filmic and 'real' space, can be re-narrated and brought into new relations.

A second mutual indeterminacy of filmic and urban space in Secret Cinema's screening originates from the way in which the post-war Vienna featured in The Third Man is split into occupied zones. There are four quarters, controlled, respectively, by the Americans, the Soviets, the English and the French. Each is recognizable by the flag flown and the language spoken, offering four different renditions of the Austrian city. This was reiterated by Secret Cinema's site, where characters addressed us in the various languages. But Secret 
Cinema was also a 'zone' in itself. On entry to the building we had to convert our money into the site's 'currency' and implicitly agree to go along with that territory's codes of behaviour. As such it produced a further deterritorialization of filmic space because its own theatrical occupation, in mimicking the politicized quarters of Vienna, exposed those too as merely a performance of space. At the same time the zone of performance marked by Secret Cinema deterritorialized and reterritorialized an area of London unpicking the determinations of that space to make it into something else, mirroring the various reterritorializations of Vienna within the film. By its very nature, occupation presupposes the contingency of place, as something that can be taken over and made to function in another way, and the map that Secret Cinema sent to show us where to meet playfully engaged this idea, mapping the film world across Barbican, London, suggesting the site as open to being rewritten.

Through processes like those described above, Secret Cinema encouraged spectators to perceive urban space-time in a particular way, engineering a vision of the city as malleable. By bringing urban sites into performative relation with filmic any-spacewhatevers, it draws attention to the city itself as an indeterminate space ripe for recreations and retellings. In this way, the any-space-whatever characterizes the regime of vision through which Secret Cinema sees the city. In a comparable account of how exhibition practices impact ways of seeing the city, Crary argues that the panorama 'provided an imaginary unity and coherence to an external world that, in the context of urbanization, was increasingly incoherent' (2002: 21). In Secret Cinema's case, its way of seeing arguably provides an imagined malleability of urban space that can be related to its own urban context. Just as Crary links the panorama’s ‘imaginary unity’ to the 'incoherent' urbanization of the time, I would argue that Secret Cinema's unsettled and flexible urban imaginary corresponds to the post-recession city it is prominent within, where, as foregrounded and perpetuated by pop-up culture, spaces change use rapidly and unpredictably. 
The relationship between film and spatiotemporal flexibility developed within pop-up culture has also been identified in other filmic uses of urban sites. Vanessa Matthews has discussed the re-use of a distillery in Toronto as a film set. She suggests that the ex-industrial building's transformation into numerous film worlds illuminates the 'becoming other' of the site, 'imbued with an endless lexicon of meanings which can be used to fabricate other spaces, places and times in films'. Her discussion of 'the flexibility of place to contain meaning (and value) based on the practices which occur within and outside it' (Matthews 2010: 181) resonates with my argument about Secret Cinema's urban imaginary. In fact, the Farmiloe building used to screen The Third Man has, like the distillery described by Matthews, been a popular site for location shooting since it became disused as a factory in 1999. Its use by Secret Cinema to create the world of The Third Man followed its transformation for various popular films including The Dark Knight (Nolan, 2008) and Inception (Nolan, 2010). Matthews' article questions 'What is a distillery when it can become a tire manufacturing plant (Tommy Boy), a concentration camp (X-Men) or a prison (Chicago)' and argues that the various assemblages the site is brought into via its relationship with films disrupt 'singular claims to space by highlighting simultaneous realities' (2010: 181-82). Likewise, the regime of vision generated by Secret Cinema is one in which urban space is cast as flexible and re-writeable, open to being transformed and performed in myriad ways.

Secret Cinema’s deterritorializations and reterritorializations of urban space are, however, as should be recognized, normatively geared towards commercial ends. The anyspace-whatevers it creates in the city are not strictly indeterminate, given that they are successfully and profitably operationalized as sites of cultural consumption. As Matthews argues of the distillery, where multiple realities are opened up they are then singularized again through the commodification of the distillery as a site to be redeveloped. Ultimately, 
the use of the site for multiple film worlds 'created a place imaginary that could be packaged and disseminated' in order to smooth 'capital flows' and allow the site to be remade to cater for middle- and upper-class tastes (Matthews 2010: 186). Secret Cinema’s rewritings of urban space are similarly instrumental in place-rebranding and gentrification. This has been argued in relation to pop-up culture more generally (Harvie 2013; Colomb 2012). Secret Cinema's potential for place rebranding can be seen clearly in the case of its recent production of Back to the Future (Zemeckis, 1985) in 2014, which took place by the Olympic Park in Stratford, an area of London synonymous with the redevelopment and gentrification that followed the 2012 Olympic Games. Secret Cinema’s screening arguably assisted the generation of interest in the area from those with high disposable incomes by attracting audiences to the site and glamorizing the location through its encounter with the film world of Back to the Future - a film that can be read as partly concerning urban change over time. As Pratt and San Juan argue, the potential of pop-up cinemas for 'serious play' is often in tension with their utility for the festivalization of public space. The way of seeing generated by Secret Cinema’s productions certainly straddles these conflicting prerogatives.

\section{Reading Secret Cinema: perceptual continuums and the out-of-field}

As the previous section illuminated, the deterritorializations and reterritorializations enacted by Secret Cinema do not just affect the urban site but act on filmic space too as it is reciprocally destabilized by becoming a part of the assemblage constituting the event of exhibition. Through this process, a 'perceptual continuum' is generated within which the meaning of the film is transformed via urban space and vice versa. In addressing the workings of this perceptual continuum, to which I now turn, the politics of Secret Cinema's deterritorializations and reterritorializations of urban space, as uncovered immediately above, 
are important to keep in mind. If the site of spectatorship affects the meaning of a film, this is not limited to the artistic decisions of the exhibitors but extends to the broader conditions of that site and its production.

Like Holly, who finds himself investigating Harry’s whereabouts, Secret Cinema’s staging of The Third Man turned its spectators into detectives and writers as we tried to uncover and then piece together the world in which we had been immersed. Crucially, this detective work not only involved exploring the site but continued throughout the viewing of the film itself. My ethnographic notes remind me that 'seeing the film was like ordering the clues we had accumulated, as if somebody had pieced them all together so that gradually, watching the film, we understood the things we had encountered and had the gaps filled in'. A perceptual continuum was generated whereby imaginative engagement with the film world moved between the film text and the site.

The workings of this continuum may be profitably explored in relation to Deleuze's conception of the out-of-field and its differing functions within the 'movement-image' and the 'time-image’. In Cinema 1, Deleuze explores how movement works within classical, preWWII cinema. He engages the Bergsonian notion of the 'whole' to explain the temporality of classical film images. Adapted from Bergson's concept of 'duration', the 'whole’ refers to an ever-evolving totality. The fact that this totality is always evolving is important because it enables the movement of parts within it. Real movement of parts cannot occur if the whole is pre-given because that would make movement merely a mechanical unfolding towards that pre-given state, rather than a generation of new qualities (Deleuze 2005: 7-8). Deleuze argues that in classical cinema the images and sets of images on screen open up onto this unsettled whole, so that their movements are generative of qualitative changes within it. The relationship between on-screen and off-screen images, and the whole, which is their sum, is articulated through what Deleuze terms the 'out-of-field'. 
The out-of-field is something implied by but not visible within a frame and explains the process through which images are linked together, indicating how those on the screen refer to something currently off-screen that will later (or has already) become visible. More precisely, there are two ways in which this occurs. First, there is an out-of-field that refers to something just 'to-the-side' of the frame. Second, there is a more radical 'out-of-field' that refers to a virtual relationship with the 'whole' that is indirectly expressed (Deleuze 2013: 2) - for example, through the presentation of an image that alters the meaning of that evolving totality. Both these notions can be applied to Secret Cinema. In taking up Deleuze’s illumination of how movement and temporality are produced on-screen we can see how, here, filmic images are linked with urban space to produce a duration that moves (as in Hansen's continuum) between the on- and the off-screen entertainment. Before I explore this, it is necessary to examine the different ways in which images relate beyond themselves in the time-image. For Deleuze, time-images, which characterize modern cinema, do not create time through the out-of-field as it features in the movement-image. In the time-image the whole, which formerly existed 'beyond' the images, becomes an 'outside' that is internalized, located, more nebulously, in the interstitial spacing between images (Deleuze 2005: 184). Here, the out-of-field is supplanted as movement ceases to be a straightforward linking of images. Images now come to relate to their own virtual image - that is, to their possibilities to be otherwise. It is this relationship that generates a direct representation of time. This happens because the correspondence of images to their own virtual image evokes the gulf between the image as it is and its myriad possibilities to be enacted differently. This possibility of difference is, for Deleuze, time in its essence. Thus, while the movement-image is an indirect representation of time, because the whole is something that could theoretically be recovered in its entirety (Rushton 2012: 4), the time-image evokes time directly insofar as the insertion of the outside into the interstices introduces something inherently incommensurable 
(Rodowick 1997: 279): the difference between the actual image and its corresponding virtual image. The time-image therefore works through an avowal of resolute incompleteness as each image conjures up its own capacity to be otherwise (Deleuze 2013: 280).

Secret Cinema cannot be neatly read through either the movement-image or the timeimage. Its relation of filmic images to urban space is plainly not what Deleuze is imagining in his discussion of the 'off-screen'. However, holding it up against both is helpful in interrogating the functions of the continuum Secret Cinema creates through its linking of onand off-screen images. The movement-image, as David Rodowick has argued, entails a 'grand image of truth' in which world spectator and film image are united as 'the integration of parts into ensembles, and ensembles into wholes culminat[ing] in a totality' (Rodowick 1997: 12). The movement-image, then, helps to explore how Secret Cinema’s screening of The Third Man, in making its spectators detectives, seemingly unites them in a whole that is discoverable, engineering an exploration that culminates in solving the mystery through the act of film-viewing. The time-image, on the other hand, in its avowal of incommensurability, will assist in interrogating the elements of Secret Cinema's screening that are not so easily reconciled. In what follows, I explore two examples from Secret Cinema's exhibition of The Third Man: first, the staging of the 'ferris-wheel scene' and, second, how the idea of 'the third man' introduced in the film reacts with Secret Cinema's mode of exhibition. The first account will show how the out-of-field can illuminate the connection of filmic to 'real' space in Secret Cinema’s screening - reel-to-real - while the second uses the time-image to consider elements of incommensurability in Secret Cinema's screening.

\section{The ferris wheel}


What I am calling the 'ferris wheel scene' comes towards the end of The Third Man, after Holly has uncovered Harry's lies and criminal activities, including, importantly, the fact that he has killed innocent people by selling diluted penicillin for profit. Throughout The Third Man, vertical levels are used to highlight geographies of scale and morality, and here Harry tries to justify his peddling of diluted penicillin to Holly by taking him up on a ferris wheel looking over the city and using the perspective gained from their height to validate his argument.

Pointing to the people on the ground below them, Harry says, 'Victims? ... Don't be melodramatic. Look down there. Tell me. Would you really feel any pity if one of those dots stopped moving forever? If I offered you twenty thousand pounds for every dot that stopped, would you really, old man, tell me to keep my money...?’ Harry thus justifies his crime by refiguring 'victims' as dots seen from afar, adopting a perspective where the consequences of his actions have no measure. This relationship between perspective and ethics was foregrounded by Secret Cinema's staging of the film. During the evening, they handed out programmes that featured words from the speech Harry gives on the ferris wheel, stating ‘NOBODY THINKS IN TERMS OF HUMAN BEINGS. GOVERNMENTS DON’T. WHY SHOULD WE?’ The programme goes on to explain the importance of this quotation, arguing that ' 60 years later this film continues to resonate. It would appear that Harry Lime is alive and staging the breakdown of Europe... the potential collapse of the Euro, the restructuring of the World economy, the breakdown of democracy'. Staying within the imaginative space of the film, the statement connects the politics of The Third Man with contemporary issues.

As I was exploring the site, actors playing Harry and Holly performed the ferris wheel scene from a ledge on an upper floor. I stood on the ground craning up to watch them so that, as Harry delivered his speech, I became one of the dots they gestured down to. Later, when the film was shown and I watched the scene and saw Harry looking down at the dots, I 
remembered myself, looking back up. In Deleuze’s terms, I had become an out-of-field of the first kind, the thing alluded to just outside of the frame - in this case the unseen face of a dot too far away to be considered a person. The actualization of this out-of-field within the film image therefore added my own experience to the film space, giving the dots a humanity that qualitatively changed the nature of the scene.

Through this process, the filmic and urban spaces were joined in a perceptual continuum. Secret Cinema's recreation of a site and a scene from the film meant that I had an embodied experience that corresponded to the film text as if the site explored was just 'tothe-side' of the on-screen image, ready to be conjured up through the out-of-field. As Rodowick maintains, the out-of-field is the means by which spaces are added to one another (Rodowick 1997: 48), and here it is 'real', non-filmic, space that is added to the spaces onscreen via the out-of-field.

Furthermore, because the programme connected the film to contemporary issues, becoming a dot meant not only stirring empathy for Harry’s victims but also acknowledging the humanity of the modern world's victims too. This amounts to the second kind of out-offield, evoking the entirety of 'real space' in such a way that the film's 'moral' gains a generative function within the wider city, becoming a critique of contemporary politics, or, in Pratt and San Juan's terms, an act of serious play. Because of the way film was made to leak into 'real' space, the second out-of-field, the virtual relation to the whole, was manifested as the images on-screen made qualitative changes to the whole as a site-cinema assemblage. Thus, in the light of Hansen's perceptual continuum, we can see how the 'non-filmic activities' accompanying the images change the film's 'meaning and effect on the viewer' (Hansen 1991: 93) as they are enacted by the two types of out-of-field. The event becomes an assemblage of film space and urban space, and the whole they open out onto, the entirety of the 'real' world. 


\section{The third man}

The neat relation between filmic and urban space that Secret Cinema generates in instances like the ferris-wheel scene stands in tension with elements of incommensurability in their event that the time-image can help us to explore. The eponymous 'third man' is very much a figure of such incommensurability, and here I will explore the significance of the third man in order to illuminate that which remains irreconcilable in the coming together of filmic and urban space engineered by Secret Cinema.

In the film, the 'third man' is the mysterious third witness to the 'accident' that 'kills' Harry: a man spotted at the scene but not identified. As it turns out, this 'third man' is Harry himself who, having staged his death, is fleeing the scene. We can understand the significance of 'the third man' in the light of the famous 'third man' argument that Aristotle developed from Plato. For Plato, the theory of forms enables us to affirm and identify categories to which individual things in the world, which Plato calls 'particulars', belong. What makes men 'men', despite their differences, is that they all share in the ideal form of man. For every category of things, be it men, tables or flowers, there is a corresponding form that gives them their shared identity. However, this theory generates an infinite regress problem. If things with a common essence must share in the same form, and the form of man has something in common with men, because it is their ideal version, there must be another form that explains the commonality between men and the form of man, and so on and so on. An infinite regress is created in which the identity of particulars cannot be affirmed, because it relies on an ever-expanding field of abstract forms. In the film Holly’s quest to identify the ‘third man' can then be understood as an attempt to identify a particular (the unknown witness) in an arena where there is nothing to ground its identity. Like the infinite regress of 
the third man argument, Holly's pursuit only overturns more unsolvable problems as he falls deeper into the city's mysteries. The expanding field of abstract forms is evoked in the film's rendition of post-war Vienna, which is itself expansive and unsettled. A typical film noir landscape, the city is characterized by dark streets filmed at disorientating angels, signifying the equally shadowy and elusive nature of truth (Hayward 2013: 150). It is also filled with unidentified figures among which the elusive ‘third man’ becomes the archetypal modern stranger. Thus, whereas Harry's butler suggests that the third man, the witness to the accident, might have been 'just anybody’, the film’s triumph is in identifying the third man as Harry himself. In other words, Harry was his own witness, and insofar as a witness's role is to validate an event, Harry becomes his own validation, thus resolving the problem of infinite regress.

In fact, the most peculiar circumstance surrounding Harry’s 'death' is that there were, as Holly comments, 'no strangers there at all'. Harry was 'killed' by his own driver and pronounced dead by his own doctor, who just happened to be passing. The anonymous city becomes, uncannily, a space populated by known others. The way that the abstract becomes familiar in The Third Man was reiterated by Secret Cinema's own practice that brought us as spectators up close to the film's mysteries. Indeed Secret Cinema’s promise is to provide personal encounters with film worlds in contrast to the impersonal experience of the multiplex (Anon. 2011), and to produce a tangible yet fantastical meeting with the usually elusive presence of the cinematic in the city. Just as, in the film, the abstract third man is revealed to be strangely familiar, the usually impersonal nature or elusive presence of the cinematic is produced by Secret Cinema as something that can be encountered personally. Hansen has suggested that the elements of live performance in early film exhibition asserted the incompleteness of film as a circulated commodity, which needed to be completed through ‘improvisation, interpretation and unpredictability’ during the public event (Hansen 1995: 
208). The live elements of film exhibition gave spectators a more personal involvement with the film content, particularly as they often responded specifically to the demographic in attendance. For example, Hansen describes how movie theatres in Chicago, which largely catered for African Americans, would draw on Southern black performance, jazz and blues in producing entertainment to accompany white mainstream productions, altering the meaning of that text (Hansen 1995: 209). Secret Cinema also asserts the incompleteness of film as a circulated commodity, insisting instead on a film as something that can be imagined and exhibited in numerous ways, and creating screenings that must be activated anew by the engagements of each temporary public.

And yet, while the movement towards de-abstraction in The Third Man might make the unknowable stranger a familiar face, it simultaneously makes the familiar sinister, exposing the knowledge we thought we had as false. Harry, Holly’s friend and Anna's lover, is revealed as the city's villain and the cold face of capitalism, concerned with profit at the expense of the 'dots'. The alarm sounded by The Third Man is not, therefore, intended to signal the encountering of a merciless world, but to highlight that what is assumed to be known is deceptive - that a person who is assumed to be a friend may turn out, as Holly finds, to be a stranger, a merciless and remote figure who we cannot reconcile with the person we thought we knew.

If Secret Cinema's staging of The Third Man made us detectives in order to, like Holly, uncover the true nature of Harry then we could take the opportunity to turn the magnifying glass on Secret Cinema itself and make a parallel revelation about their practice here too. Just as the familiar figure of Harry is revealed as a malevolent capitalist, it is important to note that Secret Cinema is a highly profitable commercial enterprise (which now charges $£ 75$ for tickets) and part of a film industry driven by profit and riddled with inequalities and exploitations (Aitken and Dixon 2006). Indeed, Secret Cinema’s recent 
expansion of their enterprise into the company 'Secret Space', which will find and acquire vacant sites in the city, shows their position of power in contestations over use of vacant spaces, which, in London are increasingly managed in ways that negate equal access (Colomb 2012; Tonkiss 2013). While Riggall asserts that, for Secret Space, 'space belongs to the people' (cited in Rosser 2014), the job description for the 'Head of Secret Space' frames the project as important within Secret Cinema's 'real estate arm', through which disused city spaces can be mapped and incorporated in Secret Cinema’s network (Secret Cinema 2015). In 'Postscript on the societies of control' Deleuze describes how a historical shift can be traced from Foucault's society of discipline, enacted through enclosed spaces, to a society of geographically dispersed ‘free floating control’ (Deleuze 1992). Secret Cinema’s colonization of the city's indeterminate spaces seems exemplary of a contemporary intensification of the society of control, in that it aims to own, govern and profit from the interstitial and nomadic urban geographies that have historically provided secrecy and escape. As Hansen notes with respect to early cinema, if exhibitors catered to specific demographics, 'this was not because the individual exhibitor believed in defending communal culture against the onslaught of monopolization, but because the format was profitable and competitive' (Hansen 1991: 10001), and, of course, Secret Cinema's personal encounters with film worlds also follow the profit motive, playing into a contemporary taste for the clandestine and the unexpected. There is, therefore, an incommensurability between Secret Cinema's offer of a personal experience that critiques corporate profiteering (by making us dots) and the orientations of that experience towards profit and power over urban space - an incommensurability of the same order as that generated by the knowledge that Holly and Anna have of Harry.

This dimension of Secret Cinema's screening is most clearly understood in relation to the time-image and its incommensurability. Rushton argues that 'Films of the movementimage are typically defined by a problem or set of problems for which a solution must be 
located' (Rushton 2012: 4). However, in the case of The Third Man, solutions to problems are problems in themselves. In the film, the infinite regress problem of the third man and the mystery of what happened to Harry are solved, but this opens up new problems and evokes a parallel problem on the level of Secret Cinema's screening. Although knowledge of 'what happened' is restored, as Harry is found to be his own 'killer', intimate knowledge of a person is undermined because the friend and lover that Holly and Anna thought they knew is unmasked as a villain. The two kinds of knowledge do not negate each other, as negation would be a form of solution. Instead, their irreconcilability generates problems. First, a philosophical problem is suggested, the problem of the indiscernibility of an enigmatic other, and, second, a narrative problem is created in respect of what Anna and Holly will do in light of the discovery that the man they sought to have back in their lives is not who they thought he was. In terms of the expanded geography of Secret Cinema, the incommensurability of the seemingly intimate experience of film that the event provides and its commercial orientation creates an equivalent gap. Again, the commercial orientation does not necessarily negate the personal experience but stands in tension with it, opening up an incommensurability by asserting a personal space for 'the people' while engineering a quite different sort of city.

\section{Conclusions}

Secret Cinema presents fascinating challenges for thinking through the multiplicity of encounters between film and the urban in a context where those encounters are deliberately staged. I have developed a particular approach to those encounters, taking up a number of Deleuzian concepts as a means of interrogating the regimes of vision that Secret Cinema encourages and with the aim of exploring how the meaning of a film screening is produced through the interplay of filmic images and urban sites. 
In considering the effect that Secret Cinema's mode of exhibition has on perceptions of the urban, I have accentuated the value of Deleuze's concept of the any-space-whatever in this context. Against the any-space-whatever, I have characterized Secret Cinema's regime of vision as one that casts the urban as a flexible, malleable space-time and considered the relationship of this regime of vision to the spatial uncertainties and contingencies foregrounded by pop-up culture. In exploring Secret Cinema's relations between filmic images and urban site, Deleuze's notion of the out-of-field has been translated into a context where it is located not just 'off-screen' but in relation to the geography of spectatorship. I have sought to demonstrate that, through this out-of-field, a perceptual continuum is created in which on-screen images are transformed as they are linked to 'real' space, such that the site in turn takes on new meanings as it becomes an out-of-field or an outside to those images.

As stated at the outset, Deleuze's focus on time as generative makes his philosophy particularly valuable for addressing Secret Cinema and its transformative engagement of filmic and urban space. Most significantly, Deleuze’s nuanced thinking on how images relate beyond themselves enables an interrogation of the way in which film images come into transformative contact with sites of spectatorship and broader urban contexts. Secret Cinema's screening of The Third Man simultaneously presented a discoverable 'whole' and an incommensurable experience, indicating that the encounter it stages between filmic and urban space is neither singular nor straightforward. In reading Secret Cinema through Deleuze, and by drawing on accounts of early spectatorship, I have sought to develop an approach to Secret Cinema that addresses the various and conflicting transformations that occur when film texts come into contact with spectator, site and city.

\section{Acknowledgments}


I am very grateful to Harriet Hawkins, Tim Cresswell and Oliver Harris for their advice on drafts of this article. I would also like to thank David Clarke and Marcus Doel for organizing the special issue and for their valuable support.

\section{References}

Aitken, S. C. and Dixon, D. P. (2006), 'Imagining geographies of film’, Erdkunde, 60:4, pp.326-336

Andres, L. (2013), ‘Differential spaces, power hierarchy and collaborative planning: A critique of the role of temporary uses in shaping and making places', Urban Studies, 50:4, pp. 759-75.

Anon. (2011), The Guardian, http://www.theguardian.com/honda-dream-factory/hondadream-factory-social-cinema. Accessed 19 Febraury 2015.

(2014), “Secret Cinema founder Fabien Riggall on future of cinema”, Screen Daily, $19^{\text {th }}$ September, http://www.screendaily.com/comment/secret-cinema-founder-on-futureof-cinema/5077742.article. Accessed 19 February 2015.

(2015), Secret Cinema, http://www.secretcinema.org/recruitment/sc---hos.html.

Accessed 24 February 2015. 
Appearhere-(2015),- Appearhere, https://www.appearhere.co.uk/tenants ._fAccessed 14 April 2015\}.

Bishop, P. and Williams, L. (2012), The Temporary City, Abingdon : Routledge.

Campbell, J. (2005), Film and Cinema Spectatorship, Cambridge: Polity.

Clarke, D. (1997), The Cinematic City, London: Routledge.

Clarke, D. B. and Doel, M. A. (2005), 'Engineering space and time: Moving Pictures and motionless trips', Journal of Historical Geography, 31:1, pp. 41-60.

Colomb, C. (2012), 'Pushing the urban frontier: Temporary uses of space, city marketing, and the creative city', Journal of Urban Affairs, 34:2, pp. 131-52.

Crary, J. (1990), Techniques of the Observer, London, England, Cambridge, MA: MIT Press.

(2002), 'Gericault, the panorama, and sites of reality in the early nineteenth century’, Grey Room, 9, pp. 5-25.

Cresswell, T. and Dixon, D. (2002), Engaging Film: Geographies of Mobility and Identity, Maryland, Oxford: Rowman and Littlefield Publishers Inc.

Deleuze, G. (1992), 'Postscript on the societies of control', October, 59, Winter, pp. 3-7. 
(2005), Cinema 1, London and New York: Continuum.

(2013), Cinema II The Time Image, London: Bloomsbury.

Della Dora, V. (2009), ‘Travelling Landscape-objects’, Progress in Human Geography, 33:3, pp. 334-54.

Deslandes, A. (2013), 'Exemplary amateurism, thoughts on DIY urbanism', Cultural Studies Review, 19:1, pp. 216-27.

Dittmer, J. (2014), ‘Narrating urban assemblages - Chris Ware and building stories’, Social and Cultural Geography, 15:5, pp. 477-503.

Doel, M. A. and Clarke, D. B. (2007), ‘Afterimages’, Environment and Planning D: Society and Space, 25:5, pp. 890-910.

Escher, A. (2006), 'The geography of cinema - a cinematic world', Erdkunde, 60:4. Pp. 307314

Gandy, M. (2014), Cinematic Landscapes, Presentation at Kings College London's Geography, Film annd Visual Cultures Symposium, London. 30 ${ }^{\text {th }}$ April

Graziano, V. and Ferreri, M. (2014), 'Passion without objects young graduates and the politics of temporary art spaces’, Recherches sociologiques et anthropologiques, 45:2, pp. 83-102. 
Gunning, T. (1986), 'The cinema of attractions: Early film, its spectator and the avant-garde', Wide Angle, 8:3, pp. 63-70.

(1993), “"Now You See it, Now You Don't”: The temporality of the cinema of attractions', Velvet Light Trap, Fall 93:23. pp. 3-14

Hansen, M. (1991), Babel and Babylon, London, Cambridge: Harvard University Press.

(1995), 'Early cinema, late cinema: Transformations of the public sphere’, in L.

Williams (ed.), Viewing Positions, Ways of Seeing Film, New Brunswick: Rugters University Press. pp. 197-210

Harvie, J. (2013), Fair Play, Hampshire: Palgrave Macmillan.

Hayward, S. (2013), Cinema Studies, The Key Concepts, Abingdon, Oxon: Routledge.

Iveson, K. (2013), 'Cities within the city: Do-it-yourself urbanism and the right to the city', International Jounral of Urban and Regional Research, 37:3, pp. 941-56.

Kassovitz, Mathieu (1995), La Haine, France: Mathieu Kassovitz.

Lashua, B. D. (2013), 'Pop-up cinema and place-shaping: Urban cultural heritage at Marshall’s Mill', Journal of Policy Research in Tourism, Leisure and Events, 5:2, pp. 123-38. 
Marks, L. (2002), Touch: Sesuous Theory and Multisensory Media. Minneapolis, London: University of Minnesota Press.

Matthews, V. (2010), 'Set appeal: Film spacea and urban redevelopment', Social and Cultural Geography, 11:2, pp. 171-90.

Mulvey, L. (1975), Visual Pleasure and Narrative Cinema, https://www.amherst.edu/system/files/media/1021/Laura\%20Mulvey,\%20Visual\%20 Pleasure.pdf. Accessed 25 February 2015.

Nemeth, J. and Langhorst, J. (2014), 'Rethinking urban transformation: Temporary uses for vacant land', Cities, 40:B, pp. 143-50.

Nolan, Christopher (2008), The Dark Knight, USA and UK: Legendary Pictures. (2010), Inception, USA and UK: Legendary Pictures.

O’Sullivan, Simon (2006) Art Encounters Deleuze and Guattari: Beyond Representation, Hampshire and New York, Palgrave Macmillan

Pinder, D. (2011), ‘Cities: Moving, plugging in, floating, dissolving’, in T. Cresswell and P. Merriman (eds), Geographies of Mobilities: Practices, Spaces, Subjects, Farnham and Burlington: Ashgate, pp. 167-89. 
Pratt, G. and San Juan, M. (2014), Film and Urban Space, Critical Possibilities, Edinburgh: Edinburgh University Press.

Rall, E. L. and Haase, D. (2011), 'Creative intervention in a dynamic city: A sustainability assesment of an interim use strategy for brownfields in Leipzig, Germany’, Landscape and Urban Planning, 100:3, pp. 189-201.

Reed, Carol (1949), The Third Man, UK: Carol Reed's Production.

Roberts, L. (2012), Film, Mobility and Urban Space, A Cinematic Geography of Liverpool, Liverpool: Liverpool University Press.

Rodowick, D. (1997), Gilles Deleuze’s Time Machine, Durham and London: Duke University Press.

Rosser, M. (2014), 'Secret Cinema founder reveals Secret Space details’, Screen Daily, September 2014, http://www.screendaily.com/news/secret-cinema-founder-revealssecret-space/5077743.article.

Accessed 24 February 2015.

Rushton, R. (2012), Cinema After Deleuze, London, New York: Continuum.

Shiel, M. and Fitzmaurice, T. (2001), Cinema and the City: Film and Urban Socities in a Global Context, Oxford, Malden : Blackwell Publishers. 
Sobchack, V. (2004), Carnal Thoughts: Embodiment and Moving Image Culture, London, Berkeley: University of California Press.

Tardiveau, A. and Mallo, D. (2014), 'Unpacking and challenging habitus: An approach to temporary urbanism as a socially engaged practice', Journal of Urban Design, 19:4, pp. 456-72.

Tonkiss, F. (2013), ‘Austerity Urbanism and the makeshift city’, City: Analysis of Urban Trends, Culture, Theory, Policy, Action, 17:3, pp. 312-24.

Zemeckis, Robert (1985), Back to the Future, United States: Amblin Entertainment.

Zonn, L. (2007), 'Going to the movies: The filmic site as geographic endeavor', Aether the Journal of Media Geography, 1:Fall, pp. 63-67.

\section{Contributor details}

Ella Harris is a Ph.D. candidate in Cultural Geography at Royal Holloway, University of London. Her Ph.D. thesis explores ways in which space-time is distributed and imagined within pop-up culture in London. Methodologically, she uses interactive documentary to engage with non-linear spatio-temporal imaginaries. Ella has an M.A. in Cultural Geography (Royal Holloway) and a B.A. in English Language and Literature (Balliol College, Oxford). She has previously published on spatio-temporal imaginaries in pop-up culture (Geography Compass) and has forthcoming work on Shipping Container Architectures (The Craft 
Economy edited edition) and Interactive Documentary. She also co-organizes an ongoing project on 'Precarious Geographies', which includes a special issue currently in preparation.

Contact:

Department of Geography, Royal Holloway, University of London, Egham, Surrey TW20 0EX, United Kingdom.

E-mail: ellarsharris@gmail.com

Ella Harris has asserted her right under the Copyright, Designs and Patents Act, 1988, to be identified as the author of this work in the format that was submitted to Intellect Ltd.

Notes

${ }^{1}$ All images are reproduced from Secret Cinema's email correspondence. 